\title{
Pemberdayaan Pelaku Usaha Melalui Pengelolaan Usaha Wisata Di Desa Warnasari Kecamatan Pangalengan Kabupaten Bandung
}

\author{
Siti Patimah, Trisa Nur Kania, Latifah Adnani, Maun Jamaludin \\ Prodi Administrasi Bisnis Fisip Unpas \\ siti.fatimah@unpas.ac.id, trisa.nurkania@unpas.ac.id, latifah.adnani@unpas.ac.id, \\ maun.jamaludin@unpas.ac.id
}

\begin{abstract}
ABSTRCT
Warnasari Village is one of the villages that has a lot of potential including tourist attractions namely Situ Cileunca. Some complaints were obtained by the local community that tourism development was more managed by outside investors or what they called city people. They complained about the condition, where Situ Cileunca was part of their lives but they never felt they owned it. The purpose of activities is to increase understanding related to tourism potential and business management. The method of the activity carried out is training. As a result of the training activities, most of them did not understand how business management, especially marketing and HR management. Participants who participated in the Activity were 20 participants with different types of businesses. But they were very enthusiastic about participating in the training activities. Suggestions, people should be able to increase the desire to try. Besides that there is also a need for motivation so that it can increase business for the surrounding community.
\end{abstract}

Keywords: Empowerment and Management of Business 


\section{A. Pendahuluan}

Kecamatan Pangalengan Kecamatan Pangalengan terletak di bagian selatan Kabupaten Bandung yang berjarak 51 kilometer dari pusat Kota Bandung dan 23 kilometer dari Ibu kota Kabupaten Bandung yaitu Soreang. Dibatasi oleh Kecamatan Cimaung di sebelah utara, Kecamatan Talegong Kabupaten Garut di sebelah selatan, Kecamatan Pasirjambu di sebelah barat, Kecamatan Kertasari dan Kecamatan Pacet di sebelah timur. Kecamatan Pangalengan terbagi menjadi 13 desa yaitu Lamajang, Margaluyu, Margamekar, Margamukti, Margamulya, Pangalengan, Pulosari, Sukaluru, Sukamanah, Tribaktimulya, Wanasuka dan Warnasari. Pembahasan keadaan umum daerah pengabdian yang akan diuraikan berasal dari data profil Desa Warnasari, Kecamatan Pangalengan, Kabupaten Bandung.

\section{Keadaan Fisik Wilayah Desa Warnasari}

Desa Warnasari merupakan bagian dari Kecamatan Pangalengan Kabupaten Bandung Provinsi Jawa Barat. Desa Wanasari memiliki luas wilayah 2.354,119 Hektar, terletak pada

\begin{tabular}{|c|c|c|c|c|c|}
\hline \multirow{2}{*}{ No } & \multirow{2}{*}{$\begin{array}{l}\text { Jenis } \\
\text { Pekerjaan }\end{array}$} & \multicolumn{4}{|c|}{ Jenis Kelan Jumlah } \\
\hline & & Laki-laki & Perempuan & Orang & $\%$ \\
\hline 1 & Petani & 421 & 97 & 520 & 15,21 \\
\hline 2 & Buruh tani & 867 & 681 & 1.548 & 45,40 \\
\hline 3 & $\begin{array}{l}\text { Pegawai } \\
\text { negeri sipil }\end{array}$ & 12 & 14 & $\begin{array}{l}2 \\
6\end{array}$ & 0,77 \\
\hline 4 & $\begin{array}{l}\text { Pengrajin } \\
\text { industri } \\
\text { rumah } \\
\text { tangga }\end{array}$ & 19 & 43 & $\begin{array}{l}6 \\
2\end{array}$ & 1,81 \\
\hline 5 & $\begin{array}{l}\text { Pedagang } \\
\text { keliling }\end{array}$ & 228 & 129 & 357 & 10,47 \\
\hline 6 & Peternak & 394 & 21 & 415 & 12,17 \\
\hline 8 & Lainnya & 222 & 261 & 483 & 14,17 \\
\hline & Total & 2.163 & 1.248 & 3.411 & 100,0 \\
\hline
\end{tabular}

ketinggian \pm 1442 mdpl dan memiliki suhu udara rata-rata $12^{\mathrm{O}} \mathrm{C}-25^{\circ} \mathrm{C}$. Batas wilayah Desa Wanasari adalah :

Sebelah utara: Desa Pulosari

Sebelah timur: Desa Pulosari

Sebelah selatan: Desa Margaluyu

Sebelah barat: Kecamatan Pasir Jambu

Desa Warnasari memiliki 17 Rukun Warga dan 17 kampung yaitu Baru Taraje, Ciawitali, Cibeunying, Cibunihayu, Cidurian, Cipangisikan, Citiis, Kapas, Kiaracondong, Munjul, Neglasari, Padahurip, Palayangan, Parabon, Pasir Ucing, Singkur, dan Warnasari. Lokasi TPK Warnasari berada didepan Jalan utama Desa Warnasari di RW 02 Kampung Wanasari berjarak \pm 300 meter ke sebelah barat dari kantor Desa Warnasari. Penempatan TPK

Warnasari yang terletak di lokasi pusat desa mudah dijangkau oleh para peternak di daerah utara dan selatan serta memudahkan truk untuk mendistribusikan susu yang dikumpulkan peternak ke lokasi industri pengolahan susu (PT. Frissian Flag).

\section{Keadaan Penduduk Desa Warnasari}

Pola guna lahan berdasarkan Monografi Desa Warnasari pada tahun 2017, Tata guna lahan Desa Warnasari adalah sebagai berikut :

\section{Keadaan Penduduk Desa Warnasari} yang terbesar yaitu lahan perhutanan seluas 1.352 Hektar (57,44\%). Lahan perhutanan biasa dimanfaatkan oleh para peternak untuk mencari pakan hijau rumput terutama ketika musim kemarau. Luas pemukiman sebesar 51,003 Ha ditempati oleh 2.613 kepala keluarga dengan total penduduk 8.748 jiwa yang terdiri dari 4.396 laki-laki dan 4.352 perempuan.

\section{Mata Pencaharian Penduduk}

Mata pencaharian warga desa Warnasari pada tahun 2017 disajikan sebagai berikut : Tabel 3. Mata Pencaharian Penduduk Desa Wanasari

Sumber : Monografi Desa Warnasari Tahun 2017.

Tabel 3 menunjukkan bahwa masyarakat Desa Warnasari bekerja sebagai pengrajin industri rumah tangga dengan jumlah jiwa sebanyak $62(1,81 \%)$. Hal ini menunjukkan bahwa jumlah yang relative minim dimana di Desa warnasari 
tersebut terdapat objek wisata yaitu Situ Cileunca yang memiliki potensi wisata dimana situ tersebut merupakan objek yang dapat mendatangkan pendapatan bagian amsyarakat sekitar namun tidak dijadikan sebagai peluang. Beberapa keluhan yang didapat masyarakat setempat bahwa pengembangan wisata lebih dikelola oleh investor luar atau yang mereka sebut sebagai orang kota. Mereka mengeluhkan dengan kondisi tersebut, dimana Situ Cileunca yang merupakan bagian dari kehidupan mereka tapi mereka tidak pernah merasa memiliki.

Tentunya dengan permasalahan tersebut perlu mendapatkan perhatian dari pemerintah dengan adanya tempat yang memiliki potensi yang dapat memberdayakan masyarakat sekitar untuk melakukan usaha di tempat wisata tersebut.

\section{b. Tujuan dan Manfaat}

1. Meningkatkan pemahaman masyarakat tentang potensi daerah yang ada di Desa Warnasari Kecamatan Pangtalengan Kabupaten Bandung.

2. Meningkatkan pemahaman masyarakat tentang pengelolaan usaha yang berkaitan dengan pemasaran dan pengelolaan SDM.

\section{B. METODE PELAKSANAAN}

Kegiatan pengabdian yang dilaksanakan di Desa Warnasari Kecamatan Pangalengan Kabupaten Bandung dilakukan melalui kegiatan pelatihan. Pelatihan adalah proses belajar bersama yang dilakukan oleh beberapa orang untuk memahami atau menguasai sesuatu pengetahuan atau keahlian tertentu. Ahsanul Minan ( 2003 : 3). Adapun metode yang dilakukan menurut $\mathrm{T}$ Hani Handoko (2012 : 115) adalah dalam bentuk Kuliah yaitu Merupakan metode tradisional dengan kemampuan penyampaian informasi, banyak peserta dan biaya relatif murah. Metode ini cenderung lebih tergantung pada komunikasi, bukan modeling. Berupa ceramah yang disampaikan secara lisan. Metode ini harus dikombinasikan dengan metode lainnya seperti diskusi dan tanya jawab karena peserta cenderung pasif disebabkan adanya komunikasi satu arah saja

\section{a. Rencana Kegiatan}

1. Persiapan Kegiatan

a. Menyusun rencana operasional kegiatan secara matang

Dalam tahap ini sebelum menyusun proposal terlebih dahulu berkoordinasi dengan tim untuk menyusun. Diantaranya adalah dengan merencanakan pelaku usaha, pembagian pekerjaan, melakukan kunjungan ke objek dalam rangka untuk mengetahui permasalahan yang dihadapi masyarakat, menyusun proposal, menentapkan materi yang akan disampaikan yang sesuai dengan permasalahan yang dihadapi masyarakat dalam hal ini pelaku usaha

b. Melakukan rapat koordinasi tim pelaksana Dalam tahap ini tim melaksanakan rapat pembagian tugas tim, mengagendakan rapat koordinasi, yang ditujukan agar pelaksanaan kegiatan mulai dari persiapan, pelaksanaan, monitoring dan evaluasi, sampai pada pembuatan atau penyusunan laporan dapat berjalan sesuai dengan rencana yang telah ditetapkan.

c. Menyiapkan masyarakat yang dalam hal ini adalah pelaku usaha di daerah wisata. Masyarakat pelaku usaha sebagai objek dalam kegiatan pengabdian didasarkan pada hasil pengamatan yang dilakukan oleh tim dan berdasarkan permasalahan yang dihadapi oleh masyarakat.

d. Menyusun jadwal kegiatan pengabdian pada masyarakat yang dilaksanakan di Di Desa Warnasari Kecamatan Pangalengan Kabupaten Bandung.

Pelaksanaan Program

a. Pelaksanaan Program Di Pelaku Usaha Di Desa Warnasari

Pelaksanaan Pelatihan yang disampaikan kepada masyarakat pelaku usaha terkait dengan pelatihan pengelolaan usaha wisata 
yang terkait dengan pemasaran dan pengelolaan SDM.

b. Pelaksanaan Monitoring dan Evaluasi Pelaksanaan Monitoring merupakan kegiatan yang di laksanakan oleh tim pelaksana kegiatan dalam mengamati dan memonitor pelaksanaan pelatihan yang di jalankan atau di laksanakan oleh instruktur, sedangkan pelaksanaan evaluasi merupakan kegiatan penilaian yang dilaksanakan oleh tim pelaksana pasca program pelatihan, Evaluasi dan monitoring ini dilaksanakan untuk melihat hasil dari pelaksanaan kegiatan. Dari hasil kegiatan ini akan menjadi rujukan bagi pihak-pihak terkait untuk terus dapat memberikan kemanfaatan baik bagi masyarakat maupun pihak tertentu seperti pemerintah setempat maupun pemerintah Kabupaten Bandung khususnya.

\section{c. Membuat Laporan}

Pembuatan laporan kegiatan pengabdian pada masyarakat pelaku usaha di Desa Warnasari ini di dasarkan pada hasil pelaksanaan kegiatan, monitoring, dan evaluasi.

\section{HASIL DAN PEMBAHASAN}

\section{a. Koordinasi Tim}

Kegiatan Pengabdian Kepada Masyarakat yang dilaksanakan oleh Tim Prodi Administrasi Fisip Unpas dengan judul “ Pemberdayaan Masyarakat Melalui Pengelolaan Usaha Wisata Di Desa Warnasari Kecamatan Pangalengan Kabupaten Bandung", dalam kegiatan ini sebagai ketua Siti Patimah,SE.,M.Si dan Anggota Dra. Trisa Nur Kania,M.Si, Latifah Adnani, SH.,M.Si, Dr.Ir. Maun Jamaludin, M.Si. Kegiatan dilaksanakan mulai Bulan Pebruari sampai dengan bulan Mei 2019. Kegiatan dimulai dengan koordinasi Tim, Tim menentukan objek pengabdian yang berdasarkan kesepakan menentukan objek pelaku usaha yang berada di Desa Warnasari Kecamatan Pangalengan Kabupaten Bandung. Informasi yang didapat bahwa pelaku usaha yang terdapat di Desa Warnasari cukup banyak karena terdapat di beberapa Dusun. Berdasarkan pengamatan tim dimana permasalahan yang dialami oleh pelaku usaha adalah terkait dengan pengelola usaha terutama terdapat potensi wisata di Desa tersebut sehingga menjadi potensi untuk pelaku usaha khususnya dan masyarakat umumnya. Masyarakat di Desa Wanasari mengeluhkan karena keberadaan situ Cileunca yang menjadi sumber wisata tidak menjadi satu tempat potensi untuk masyarakat sekitar. Mereka merasa asing dan tidak merasa memiliki. Untuk itulah Tim merasa bahwa perlunya memotivasi masyarakat untuk tidak berfikir seperti itu dan hal yang perlu dilakukan adalah memacu diri untuk mengembangkan usaha dengan keberadaan tempat wisata terutama objek wisata situ Cileunca.

\section{b. Pembagian Tugas Pelatihan dan Penjadwalan}

Hal ini selain karena masalah yang dihadapi oleh masyarakat yang dalam hal ini pelakuk usaha dan juga terkait dengan kopentensi yang dimiliki oleh tim. Dimana pada saat pelatihan untuk materi disampaikan oleh Latifah Adnani, SH.,M.Si dan Dr. Maun Jamaludin, M.Si, Sementara Siti Patimah, SE.,M.Si dan Dra, Trisa Nur Kania, M.Si. bertugas menentukan jadwal dan tugas lain menyusun jadwal serta membantu pada saat pelatihan dilaksankan. Hal lain yang bermasalah akan disampaikan pada kegiatan berikutnya. Setelah adanya pemetaan masalah yang dihadapi oleh pelaku usaha kemudian pembagian tugas atau waktu pelatihan yang akan dilaksanakan kepada pelaku usaha. Hal ini tentunya disesuaikan dengan kegiatan yang dilaksanakan oleh pelaku usaha. Karena kesibukan dari pelaku usaha di dalam menjalankan usahanya. Setelah pelaku usaha menetukan waktu untuk kegiatan pelatihan maka kami tim sepakat untuk menentukan kegiatan berikutnya yaitu mengevaluasi.

\section{c. Evaluasi dan Penyusunan Pelaporan}

Evaluasi akan dilaksanakan setelah kegiatan pelatihan dilaksanakan kepada mitra, evaluasi yang akan tim lakukan adalah beradasarkan 
hasil wawancara yang kami sampaikan kepada pelaku usaha. Apakah apa yang tim sampaikan masih kurang dipahami atau masih harus ada keberlanjutan kegiatan. Untuk mengetahui itu maka perlu adanya kegiatan pelatihan terlebih dahulu. Setelah evaluasi tim menyusun laporan yang menjadi pertanggungjawaban tim dalam melaksanakan kegiatan. Untuk itu tim sepakat untuk menyusun laporan dengan melakukan diskusi terlebih dahulu. Sehingga hal-hal apa saja yang perlu disampaikan dalam laporan dan yang pasti kegiatan pengabdian mulai dari awal penyusunan proposal hingga laporan akhir.

\section{d. Pembukaan Pelaksanaan Kegiatan Pengabdian}

Berdasarkan Pembagian Tugas dan Penjadwalan kegiatan Pemberdayaan melalui pelatihan pengelolaan usaha wisata maka kegiatan pelatihan dilaksanakan sesuai dengan kesepakatan Tim dengan masyarakat yang dalam hal ini adalah para pelaku usaha yaitu di bulan Pebruari tepat tanggal 26 tahun 2019. Kegiatan pelaksanaan pelatihan diawali dengan adanya pembukaan di Aula di Desa Wanasari Kecamatan Pangalengan Kabupaten Bandung. Kegiatan. Pada Acara pembukaan yang dalam hal ini dihadiri oleh masyarakat warnasari yang terdiri dari beberapa Dusun serta para aparat Desa. Selain itu juga dari beberapa perwakilan yang pada saat pembukaan di wakili oleh beberapa Dosen dan Tim yang akan melaksanakan kegiatan. Pada Saat itu juga di hadiri oleh beberapa aparat Pemerintah mulai dari Desa yang dalam hal ini langsung hadir Bapak Kepala Desa, kemudian dari kecamatan yang diwakili langsung oleh Bapak Camat, Serta dari Kabupaten Bandung yang dalam hal ini wakili dari Dinas Pemberdayaan. Untuk perwakilan dari Fisiplangsung dihadiri oleh Bapak Dekan Fisip Unpas Yaitu Dr. M. Budiana, SP.,M.Si. Setelah acara pembukaan ramah tamah sambil diselingi musik.

\section{e. Pelatihan Pengelolaan Usaha}

Keesokan harinya tanggal 27 Pebruari 2019 kegiatan pelatihan dilaksankan di Madrasah Al Azhar, Kegiatan dilaksnakan pada pukul $09.00 \mathrm{~s}, \mathrm{~d}$, pukul 12.00. Saat tiba di Madrasah peserta sebagian sudah berkumpul. Saat itu juga kami tim berupaya untuk mempersiapak keperluan untuk pelaksanaan kegiatan yang diawali dengan daftar hadir peserta serta memberikan snack setelah itu mereka dipersilahkan untuk masuk ke dalam ruangan. Peralatan dan pendukung lainnya sudah siap dan halhal lainnya juga sudah dipersiapkan. Dalam kegiatan pelatihan di hadiri 20 peserta dari 30 undangan. Hal ini disebabkan kesibukan para pelaku usaha yang tidak bisa hadir pada saat kegiatan pelatihan berlangsung. Namun dengan tidak hadirnya $1 / 3$ peserta tidak mengurangi makna dari kegiatan pelatihan pada saat kegiatan berlangsung. Dari peserta yang hadir mereka memiliki usaha yang berbeda, mulai dari usaha dagang (warung), dagang makanan gorengan, kerajinan, olahan makanan, pengolahan limbah sampah, dan lainnya. Setelah peserta selesai mengisi daftar hadir dan persiapan selesai para peseta langsung memasuki ruangan. Sebelum acara pelatihan dimulai terlebih dahulu diawali dengan pembukaan. Diawal pembukaan tim memperkenalkan nama-nama yang akan memberikan pelatihan. Setelah pembukaan dan perkenalan selanjutnya masuk pada acara pelatihan.

Pelatihan mengenai Pengelola Usaha Wisata di bawakan oleh Latifah Adnani, SH.,M.Si dan Dr. Ir. Maun Jamaludin,M.Si. sebagai narasumber. Narasumber memberikan penjelasan terkait dengan pariwisata terlebih dahulu. Kemudian contoh-contoh yang termasuk industry pariwisata yang kreatif dan inovatif. Seperti diantaranya wisata belanja dan lainnya. Kemudian menjelaskan tujuan kepariwisaatn dan hal-hal yang perlu diperhatikan pada saat mengembangkan wisata daerah. Hal yang paling penting dalam mengelola usaha wisata adalah pengelolaan sumber daya manusianya yang harus berbasis kewirausahaan. Sampai pada akhirnya 
narasumber mengakhiri memberikan penjelsan kepada para peserta.

Narasumber memberikan kesempatan kepada para peserta untuk bertanya, diawal kesempatan yang diberikan ada dua pertanyaan. Untuk kesempatan pertama pertanyaan diajukan dari Pa RW dan satu lagi dari pelaku usaha pengelola sampah. Pertanyaan 1 : Bagaimana caranya agar masyarakat di sekitar daerah Situ Cileunca bisa melakukan usaha. Karena hampir sebagian yang melakukan usaha di daerah situ Cilunca adalah orang kota atau mereka dari luar Pangalengan tetapi memiliki modal yang cukup besar. Sehingga masyarakat di sekitar sini tidak merasa memiliki dengan sumber daya yang ada di Desa Wanasari seperti diantaranya peninggalan leluhur, dan utamanya wisata Situ Cileunca.

Pertanyaan ke 2 : bagaimana caranya kami selaku usaha pengelola sampah mendapatkan modal untuk usaha yang kami jalani. Karena saat inipun kami butuh modal untuk pembelian peralatan yang harganya diperkirakan $\operatorname{Rp} 25.000 .000$. selain itu juga bagaimana cara mengelola sampah yang ramah lingkungan. Kami buat produk salah satunya dari panpers. Bagaimana tanggapan para narasumber.

Jawaban Narasumber :

Berdasarkan pertanyaan dari Bapak RW yang juga selaku pelaku usaha. kami menanggapi bahwa kondisi di daerah Wanasari ini memang cukup potensial untuk dijadikan usaha yang cukup menjanjikan. Hanya permasalahannya masyarakat harus memiliki keinginan yang kuat untuk melakukan usaha. Betul memang sebagian usaha yang ada di sekitar daerah wisata adalah para pendatang. Untuk itu perlu adanya kebijakan dari pemerintah setempat untuk mengupayakan masyarakat di Desa Warnasari mengelola usaha. Kemudian hasil olahan atau hasil karya di tempatkan di salah satu pemasaran wisata atau workshop khusus untuk para palaku usaha yang berada di Desa Wanasari. Untuk itu perlu adanya kerjasama diantara para masyarakat dan pemerintah setempat. Terkait dengan dana yang terbatas perlu adanya suatu badan usaha misalnya koperasi sebagai tempat pengelolaan usaha yang sekaligus juga memberikan pinjaman kepada para masyarakat yang melakukan usaha.Intinya kembali lagi kepada masyarakat disekitar untuk terus giat melakukan usaha. Seperti yang sudah disampaikan dalam penyampaian materi hal yang terpenting dalam mengelola wisata daerah adalah pengelolaan sumber daya manusianya yang perlu memiliki jiwa kewirausahaan. Dimana jiwa kewirausahaan itu perlu memiliki mental yang kuat, ini adalah modal utama bagi seorang yang ingin menjalankan usaha.

Kemudian untuk pertanyaan kedua yang juga dari Bapak RW, yang dalam hal ini sebagai pengelola daur ulang sampah. Dimana limbah sampah dijadikan produk yang bisa menghasilkan keuntungan bagi masyarakat sekitar. Perlu untuk dikembangkan namun ada beberapa hal yang perlu diperhatikan untuk pembuatan produk. Karena dari hasil yang diperlihatkan bahwa produk masih kurang dalam cara pembuatannnya. Misalnya untuk produk yang terbuat dari kaca perlu diperhatikan karena produk dalam bentuk monument ini ujungnya tajam. Jangan sampai produk yang dihasilkan akan menimbulkan luka bagi konsumen. Sehingga produk yang dibuat harus dibuat jangan terlalu runcing sehingga tidak membahayakan. Selain itu produk-produk dari limbah seperti panpers, ini kesannya jijik, sehingga perlu hal daur ulang yang hygienes. Perlu untuk ditinjau ulang. Namun perlu apresiasi untuk masyarakat yang sudah membuat produk dari limbah sampah. Karena sampah yang hanya akan menimbulkan bencana diharapkan dapat menjadi souvenir atau hal yang dapat bermanfaat. Kemudian terkait dengan bantuan yang diharapkan sebuah mesin daur ulang sampah dengan harga Rp 25.000.000, mudahmudahan bisa ada bantuan. Namun kembali dilihat seberapa banyak sampah yang harus didaur ulang dengan menggunakan mesin tersebut. Jika benar-benar menjadi suatu kebutuhan, diharapkan bantuan pemerintah setempat atau dana-dana hibah lain yang 
dapat menjadi solusi untuk kebutuhan yang diharapkan dari usaha daur ulang sampah.

Setelah acara pelatihan dan Tanya jawab berakhir, dilanjutkan dengan acara door prize, Pada acara door prize ini dengan cara mengajukan pertanyaan kepada para peserta. Pertanyaan yang ditanyakan adalah terkait dengan apa yang sudah disampaikan oleh narasumber. Berkaitan dengan pengelolaan usaha wisata dan Tim berasal dari mana serta mengikuti yel yel yang dicontohkan tim kepada peserta kemudian harus mengikuti apa yang di contohkan Tim. Beberapa para peserta yang ditunjuk karena sudah dapat menjawab pertanyaan yang ditanyakan oleh Tim. Sampai pada akhirnya waktu berakhir dan peserta kembali ke rumah masing-masing.

\section{E. PENUTUP}

Berdasarkan kegiatan tersebut dan untuk lebih dapat meningkatkan usaha yang dijalankan oleh pelaku usaha maka :

1. Sebaiknya pelaku usaha lebih aktif dan lebih meningkatkan keinginan untuk berusaha dalam peingkatan pengembangan usaha yang akan dijalankanya, walaupun di Desa Warnasari banyak pendantang dan pemilik usaha banyak dilakukan oleh pendatang dengan memiliki modal yang lebih. Seharusnya jadi motivasi untuk masyarakat sekitar atau dalam hal ini pelaku usaha untuk tetap semangat..

2. Sebaiknya masyarakat atau dalam hal ini pelaku usaha konsisten untuk melaksanakn pengelola usaha dengan cara yang lebih kreatif dan inovasi, karena dengan terus kreatif dan meningkatkan inovasi akan lebih meningkatkan pada peningkatan kualitas produk.

3. Perlu adanya keberpihakan pemerintah terutama memberdayakan masyarakat sekitar untuk ikut partisipasi dalam melakukan usaha dengan memanfaatkan Situ Cileunca. Hal yang perlu dilakukan adalah menyediakan tempat untuk hasil dari pelaku usaha Desa Wanasari.

\section{DAFTAR PUSTAKA}

Ahsanul Minan, 2003, Modul Pelatihan Technology of Participatory Modul tentang Tehnik Memfasilitasi Pelatihan, Seminar, dan Diskusi. Disusun oleh Tim APPROACH (Assisting the Political Parties for Capacity Building)

Gendro Salim, 2010, Panduan Bisnis Lengkap, Sinergi Media Jakarta.

Handoko T. Hani, 2012, Manajemen Personalia dan Sumberdaya Manusia,

Edisi II, Cetakan Keempat Belas, Penerbit BPFE, Yogyakar

Nur Kania Trisa dkk, 2018, Pemberdayaan Masyarakat Melalui Pelatihan Manajemen Usaha di UKM Handy Craft Miniatur Alat Musik Di Desa Cikole Kecamatan Lembang Kabupaten Bandung Barat

http://media.unpad.ac.id/thesis/200110/ 2013/200110130425_4_3573.pdf

https://eprints.uny.ac.id/7868/3/bab\%202 \%20-\%2007104244083.pdf 